\title{
Effects of Using Gamification Techniques on Achievement in Science Subject
}

Muhammad Fais bin Ismail, Zanaton H. Iksan \& Rabiatul 'Aqilah Mohamad Ariffin

To Link this Article: http://dx.doi.org/10.6007/IJARBSS/v11-i12/11769

DOI:10.6007/IJARBSS/v11-i12/11769

Received: 12 October 2021, Revised: 17 November 2021, Accepted: 01 December 2021

Published Online: 21 December 2021

In-Text Citation: (Ismail et al., 2021)

To Cite this Article: Ismail, M. F. bin, Iksan, Z. H., \& Ariffin, R. 'Aqilah M. (2021). Effects of Using Gamification Techniques on Achievement in Science Subject. International Journal of Academic Research in Business and Social Sciences, 11(12), 333-343.

\section{Copyright: (c) 2021 The Author(s)}

Published by Human Resource Management Academic Research Society (www.hrmars.com)

This article is published under the Creative Commons Attribution (CC BY 4.0) license. Anyone may reproduce, distribute, translate and create derivative works of this article (for both commercial and non0-commercial purposes), subject to full attribution to the original publication and authors. The full terms of this license may be seen

at: http://creativecommons.org/licences/by/4.0/legalcode

Vol. 11, No. 12, 2021, Pg. $333-343$

Full Terms \& Conditions of access and use can be found at http://hrmars.com/index.php/pages/detail/publication-ethics 


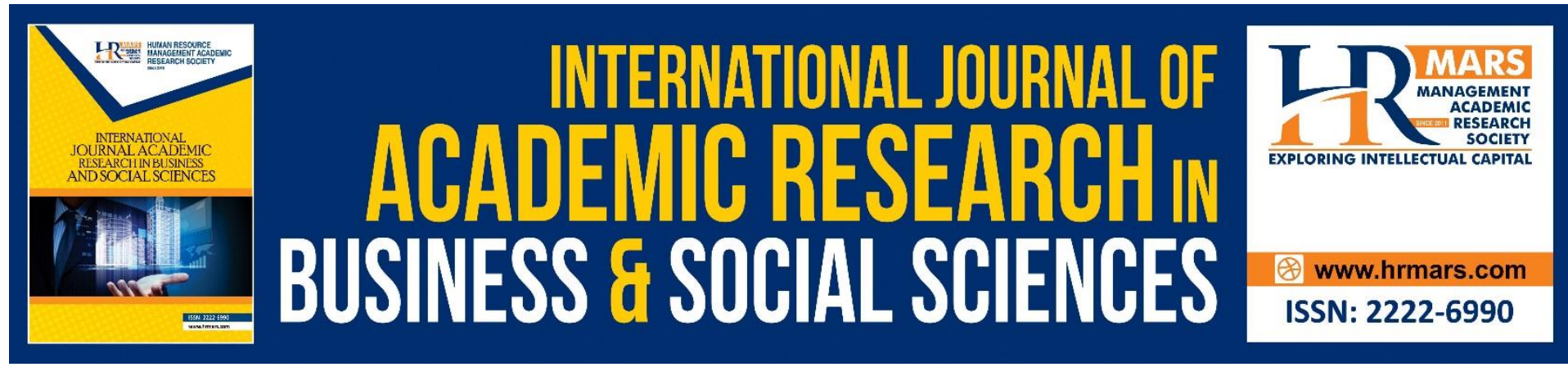

\title{
Effects of Using Gamification Techniques on Achievement in Science Subject
}

\author{
${ }^{1}$ Muhammad Fais bin Ismail, ${ }^{2}$ Zanaton H. Iksan \& ${ }^{3}$ Rabiatul \\ 'Aqilah Mohamad Ariffin \\ ${ }^{1}$ Sekolah Kebangsaan Sembirai, Jalan Kuala Abai, 89150 Kota Belud, Sabah, Malaysia, \\ ${ }^{2 \& 3}$ Fakulti Pendidikan, Universiti Kebangsaan Malaysia, 43600 UKM, Bangi Selangor, \\ Malaysia.
}

Email: ${ }^{1}$ peska@gmail.com, 22zanaton.iksan@ukm.edu.my, ${ }^{3}$ rabiatulaqilah1503@gmail.com

\begin{abstract}
Gamification is the use of games that have a design element in a non-game context with the use of elements that can stimulate and motivate its users to deliver the teaching content in the form of games. This study aims to test the effectiveness of Gamification techniques in improving understanding in topic of energy in Year 5 Science subject. A quasi-experiment study was conducted by performing pre and post-tests on 60 respondents (Year 5 students) in a primary school in the district of Kota Belud, Sabah. Descriptive and inferential analysis were used to answer the research questions using SPSS 22. There was a significant improvement in students' achievement after experiencing the Gamification technique, and also a significant improvement for the treatment group compared to the control group that used the picture card method. The findings of this study can help teachers to diversify more appropriate and effective teaching methods in line with the rapid pace of technology. The implication of this study is to expand the scope of Gamification techniques usage in schools and make course exposure to school teachers. In conclusion, Gamification techniques in learning is able to improve student achievement in the topic of Energy in Science subject.
\end{abstract}

Keywords: 21st Century Learning, Gamification, Primary School, Science Subject, Energy

\section{Introduction}

Quality education needs to be implemented in all educational institutions across the country. Among the strategies that can be used is the information technology (ICT) -based teaching approach. This ICT-based knowledge has become a starting point in improving the quality of the education system in this country. One of the ICT-based methods is the gamification technique. According to Sebastian et al (2011), gamification means the use of games that have design elements in a non-game context. In the context of education, the gamification approach refers to the use of elements that can stimulate and motivate its users so that teaching content can be delivered in the form of games (Hussain, Tan and Idris, 2014). Gamification touches on the basic instinctual wants and needs of students revolving around status and achievement, much like games. Gamification is also often used as a complement to teaching methods to achieve teaching or educational goals (Çankaya \& Karamete, 2009). 
However, the process of teaching and learning in the classroom must be implemented in line with the development of technology that is developing.

According to Freeman et al (2014) as much as 1.5 times the probability that students will fail if exposed to traditional teaching techniques compared to the involvement of an active learning environment. The same goes for the results of the study of Arip and Sa'ad (2014) that is, teachers who are more likely to use conventional teaching methods and use less teaching aids in teaching and learning will cause students to lose focus and concentration in learning. This is in line with the research problem where teachers often use conventional teaching methods such as picture cards instead of using digital games.

Zimmerman (2010) claims that traditional teaching that is still practiced is no longer relevant to be implemented today because today's young generation is facing the challenges of a more complex and technologically evolving world. The younger generation or Gen-Z who are exposed to the rapidity of technology are now more inclined to use game-shaped applications in daily life.

Therefore, the results of the researcher's observation found that Science subject teachers who teach in the schools of the study location do not diversify their teaching delivery methods. This causes students to be passive and learning objectives to be less achieved. Furthermore, more teacher-centered teaching methods and students do not appear to be actively involved in learning. In addition, Science subject teachers have less access to Science laboratories to conduct experiments. Based on the students' performance records in past examinations, the researchers found that most of the students did not master the concept of learning Science well. The researcher found that $42.42 \%$ of the total students in Year 5 did not master the minimum level for Science subjects in the examination, while only $57.58 \%$ of the total students mastered the minimum level based on the School Examination Analysis System (SAPS) database analysis.

Researchers have also identified that student absenteeism factors also greatly influence performance in Science subjects. This is because students often do not attend school because they are not interested in learning due to the presentation of teacher strategies that are less interesting. Therefore, the researcher intends to use gamification technique as a digital game design to attract the interest and motivation of students in this study thus improving the performance and mastery of students in the subject of Science. This statement is supported by a study of Smith and Kilty (2014) which says that gamification aims to motivate students as well as stimulate their interest.

The implementation of gamification as an interesting innovation has become a rejuvenation and has also been used as a learning tool among teachers in schools. Gamification can be appropriately applied as an effective teaching delivery strategy in the classroom because it suits their interests. Thus, this study aims to see the understanding of the topic of energy after using gamification techniques. To measure students' understanding, there were three research questions and hypotheses involved.

S1 Is there a difference in the mean achievement scores of the topic of Energy between the treatment and control groups in the Pre-test?

$\mathrm{H}_{01}$ There was no significant difference in the mean of achievement scores of the topic of Energy for the treatment group and the control group in the Pre-test.

S2 Is there a difference in the mean achievement scores of the topic of Energy for the treatment group in the Pre-test and Post-test? 
$\mathrm{H}_{02}$ There was no significant difference between the mean achievement scores of the topic of Energy for the treatment group in the Pre-test and Post-test.

S3 Is there a difference in the mean achievement scores of the topic of Energy for the control group in the Pre-test and Post-test?

$\mathrm{H}_{03}$ There was no significant difference between the mean achievement scores of the topic of Energy for the control group in the Pre-test and Post-test.

S4 Is there a difference in the mean achievement scores of the topic of Energy between the treatment and control groups in the Post-test?

$\mathrm{H}_{04}$ There was no significant difference between the mean achievement scores of the topic of Energy between the treatment and control groups in the Post-test.

\section{Gamification Techniques in Teaching and Learning}

Gamification is the involvement of elements that have game characteristics applied in activities unrelated to the game (Pramana, 2015). Pramana also said that this method of gamification makes the technology more effective by encouraging users' interest to be fully involved, helping to solve problems and building human interest and desire to get involved in a game. This method can also make an activity more interesting. Nowadays, gamification has become the main focus of educators in education since it was enhanced and enriched with elements of modern technology, thus enhancing the Constructivist approach in the world of education (Smith \& Kilty, 2014). The use of gamification terminology is widely used in education beginning in 2010. Overall, this terminology is widely used and accepted to refer to the use of game-based elements, such as game mechanics and dynamics, in non-game contexts to enhance experience, engagement, motivation, and to evoke a playful nature or sense in the individual (Burke, 2013).

Game mechanics have elements that play an important role in gamification. Examples of these important elements are the scoring system (points), competition with friends who play, awards or rewards in the form of badges for the level of achievement (level) in the game, ranking display (leader boards) or position (rankings) are examples of elements that must be present in gamification. Several previous studies related to the use and effects of gamification have been conducted by researchers and have shown its effectiveness in the field of education, especially to increase student motivation and involvement in learning (Kuo \& Chuang, 2016). Furthermore, the elements of the game used in gamification can provide a fun and exciting learning environment for students (Barata et al., 2013).

\section{Methodology}

This study uses a quantitative quasi - experimental design. The study participants consisted of fifth year students in a grade A primary school located in the district of Kota Belud, Sabah. The researcher also selected the respondents based on the achievement of Year 5 students' marks in the examination for the subject of Science. The justification for the selection of the study sample from this school is because the performance of students' excellence, especially in the subject of Science is not encouraging.

Accordingly, a total of 60 students from a grade A school in the district of Kota Belud, Sabah were used in this study. The sample was selected from two classes, which were Year 5 students. The selected students are students who have similar levels of knowledge and cognitive skills and they are made into a treatment group that will be taught using Gamification techniques while the control group is taught. by conventional methods. 
As for the research instrument, the Pre and Post Test Set was developed by the researcher and was validated by three experts in the field. The Pre and Post Test question set consists of 2 parts namely 10 objective questions and 5 subjective questions related to the topic of Energy.

Researchers have used Statistical Package for Social Sciences (SPSS) version 22.0 to analyse the data of the study. This method is used because statistics is a technique and method that can be used by researchers to collect, classify, summarize, organize, analyse and interpret quantitative data more accurately and systematically. Thus, score values were used to represent the data for Pre and Post Tests based on descriptive analysis.

\section{Results and Discussion}

The findings of the study are stated in this section according to the objectives of the study, namely the difference in scores between pre-test and post-test for the group undergoing the use of Gamification technique (treatment group), the difference in scores between treatment and control groups in Pre-Test, and the difference in scores between treatment groups and control in the Post Test. While the discussion of the study is described based on the research hypotheses and research findings that have been attached.

The Difference in Scores between the Treatment and Control Groups in the Pre -Test.

To answer the first research question, the data findings using independent $t$-test. The findings showed that there was no significant difference between the control class and the treatment class for the Pre-Test which were $t(58)=.471, p=.639$ which exhibited a value greater than the significance level ( $p>.05)$. Thus, the researcher can conclude that there is no change in achievement in the Pre - Test for both classes because the form of pedagogical delivery is still the same. Thus, hypothesis $\mathrm{H}_{01}$ failed to be rejected.

\section{Difference in Scores between Pre-test and Post-test for the Group Undergoing the Use of Gamification Technique (Treatment Group).}

The findings of the study showed that the R1 respondents from the treatment group showed an increase in scores of 31\% compared to the R10 respondents from the control group which was $21 \%$. Comparison of paired t-tests showed that there were significant differences for the two classes; which were control and treatment class, this difference was at a significant value, $p<.05, t=15.114, p=.000$ (Treatment Class), while for (Control Class), the value of $t=-10.157$, $p=.000$. The value of $p=.000$ is smaller than the significant value of $p<.05$, then this means that there was a significant difference for the treatment and control groups. The mean value of Pre and Post Test scores for the treatment group that is (mean $=18.5, \mathrm{SD}=6.704, \mathrm{t}(29)=$ $-15.114, p=.000)$ is higher than the mean score of Pre and Post Test for the control group ( mean $=9.6, \mathrm{SD}=5.177, \mathrm{t}(29)=-10.157, \mathrm{p}=.000)$. These findings answer the first research question in this study

\section{The Difference in Scores between Pre-test and Post-test for the Control Group}

Based on the findings of the study to answer the third research question, it was found that there is a significant difference in the mean achievement scores of the title Energy for the treatment group in the Pre and Post Test that is $t=-15.114, p=.000$, smaller than the significant level $(p<.05)$. Therefore, $\mathrm{H}_{03}$ was successfully rejected. Thus, it can be concluded that there is an increase in achievement for the control group in the Post Test compared to the Pre-Test after going through the conventional teaching and learning process. This is 
because there is an increase in the level of knowledge after students acquire knowledge from teaching and learning sessions conducted by teachers.

\section{Differences in Scores between treatment and Control Groups in the Post-test}

The findings of the study to answer the fourth research question showed that there was a significant difference between the treatment class and the control class for the Post-test that is $t(58)=8.328, p=.000$, smaller than the significant level $(p<.05)$. Therefore, it can be concluded that the use of gamification techniques can affect students' academic achievement. Thus, $\mathrm{H}_{04}$ was successfully rejected. Researcher can conclude that the use of gamification techniques can affect students' achievement and proved to improve students' academic achievement compared to the conventional teaching techniques in the school where the study was conducted.

The researcher has analysed the findings of the study which includes three types, namely descriptive statistical findings, normality test findings and also inferential statistical findings to answer the research questions. Overall, a summary of the study findings is summarized as in Table 1 below.

TABLE 1: Summary of Analysis of Study Findings

\begin{tabular}{|c|c|c|c|c|}
\hline $\mathrm{H}_{0}$ & Hypothesis Statement & Analysis & Sig. & Action \\
\hline 1 & $\begin{array}{l}\text { There was no difference between the } \\
\text { mean of the topic of Energy } \\
\text { achievement scores for the } \\
\text { treatment group and the control } \\
\text { group in the Pre-test. }\end{array}$ & $\begin{array}{l}\text { Independent } \\
\text { Sample Test }\end{array}$ & $p>.05$ & $\begin{array}{l}\mathrm{H}_{01} \\
\text { Failed to reject } \\
\text { (Accepted) }\end{array}$ \\
\hline 2 & $\begin{array}{l}\text { There was no difference in the mean } \\
\text { of the topic of Energy achievement } \\
\text { scores for the treatment group in the } \\
\text { Pre-test and Post-tests. }\end{array}$ & $\begin{array}{l}\text { Paired Sample } \\
\text { Test }\end{array}$ & $p<.05$ & $\begin{array}{l}\mathrm{H}_{02} \\
\text { Successfully } \\
\text { rejected }\end{array}$ \\
\hline 3 & $\begin{array}{l}\text { There was no difference in the mean } \\
\text { achievement scores of the topic of } \\
\text { Energy for the control group in the } \\
\text { Pre and Post-test. }\end{array}$ & $\begin{array}{l}\text { Paired Sample } \\
\text { Test }\end{array}$ & $p<.05$ & $\begin{array}{l}\mathrm{H}_{03} \\
\text { Successfully } \\
\text { rejected }\end{array}$ \\
\hline 4 & $\begin{array}{l}\text { There was no difference between the } \\
\text { achievement of the topic of Energy } \\
\text { for the treatment group and the } \\
\text { control group in the Post-test. }\end{array}$ & $\begin{array}{l}\text { Independent } \\
\text { Sample Test }\end{array}$ & $p<.05$ & $\begin{array}{l}\mathrm{H}_{04} \\
\text { Successfully } \\
\text { rejected }\end{array}$ \\
\hline
\end{tabular}

\section{Discussion}

Based on Table 1, an overall summary was made by the researcher to determine whether the constructed hypothesis was accepted or rejected in this study. Based on the table, only one hypothesis was accepted because it failed to be rejected, which was the first hypothesis, $\mathrm{H}_{01}$. The findings of the study showed that there was no difference between the mean achievement scores of the Energy title for the treatment group and the control group in the Pre -Test. This is due to the presentation of teaching techniques that were still the same which was the use of conventional methods such as picture cards. Therefore, the level of mastery of respondents in the topic of Energy at this time was still at a low level. 
The second hypothesis $\left(\mathrm{H}_{02}\right)$ and the third hypothesis $\left(\mathrm{H}_{03}\right)$ were successfully rejected because there was a significant difference in the findings of the study after undergoing $\mathrm{t}$ - test of independent samples and paired samples. The fourth hypothesis, $\mathrm{H}_{04}$ also was successfully rejected because the Gamification techniques implemented for the treatment group have shown a significant improvement compared to the control group. This clearly proves that the Gamification technique successfully improves student achievement measured by using pre and post-test scores. The findings of this study coincide with the study conducted by Sung and Hwang (2013) in the study cited by UKM researchers, Siong and Osman (2018) that the achievement of students who learn Science in a collaborative environment using educational computer games is more statistically significant compared to students who learn using conventional methods. The study of Putz et al. (2020) also found that gamification techniques have successfully improved the level of knowledge retention as well as students' learning performance. Therefore, the use of Gamification techniques is seen to be more effective than conventional learning such as the use of picture cards.

The use of Gamification techniques can help students to explore something new into their existing knowledge through constructivist theory. Ah-Nam and Osman (2017), researchers at UKM stated that in the learning process, students will interpret and make connections of new knowledge received with their existing knowledge. Students' existing knowledge is obtained from the teacher's teaching using the picture card method. After that, gamification techniques help convey new knowledge to be absorbed into students' existing knowledge. Thus, students can improve their performance better.

The researcher thinks that this Gamification technique is the most appropriate intervention in this study because it coincides with the study conducted by Rosly and Khalid (2017), researcher and lecturer at UKM where they said that the use of gamification-based learning materials was identified as an alternative to the use of effective and interesting teaching materials. Elements that attracted the attention of respondents related to Gamification techniques are the display of the Minecraft game for education which is full of animations and game mechanics system that requires competition with friends to complete the missions provided.

It is also related to the increase in student motivation when experiencing a gamificationbased learning process. According to Kalogiannakis et al (2021), the use of technology such as gamification gives a strong influence in the learning process especially science education, which is a subject that is often viewed negatively by students and they also often have difficulty in understanding the concepts in the subject. The study also found that gamification improved science teaching and students' motivation, engagement, and learning outcomes as supported by the UKM researchers and lecturers, Khaleel et al (2020). Their study has proven that student engagement and learning motivation is also influenced by the display of top 10 rankings and leader boards in real time, thereby improving students' achievement.

If we look at the comparison between the treatment and control groups, the findings show a significant difference in mean scores for the treatment group compared to the control group in the pre-test and post-tests. This statement is supported by a study conducted by UKM researchers and lecturers, Hamzah et al (2019), which states that there is a significant positive relationship between pre-test and post-test achievement for both the control and treatment groups. Findings showed higher mean scores for the treatment group than the control group. Thus, teaching using interactive game techniques has been proven to influence students' interest in lessons (Hamzah et al., 2019). Therefore, the record of student 
absenteeism to school will decrease due to improved students' interest and more motivated to engage in an active learning environment.

The use of Gamification techniques in learning can increase students' motivation to learn. Motivation plays an important role to ensure students' wellbeing. This statement is in line with a study conducted by Suhaila in the study of Khaleel et al (2016), researchers and lecturers of UKM, that through gamification activities in learning, students' motivation can be enhanced both from an intrinsic and extrinsic point of view. However, to ensure the sustainability of learning based on gamification techniques among students, several aspects need to be emphasized. Based on the study of Alamri and Almaiah (2020), the factors of fun, ease of use, usefulness, effectiveness, and effectiveness are important factors that determine the sustainability of gamification in student learning.

Teachers must be prepared to accept the reforms in education today that emphasize the use of technology as a new and more effective technique. The education system in our country needs a change to be made as a norm. This statement is in line with a study by researchers and lecturers from UKM, Soh et al (2012) who argued that changes in the education system in Malaysia should change in line with the needs of society in the 21st century. Furthermore, in the current era of the Covid-19 pandemic, online learning should be used as much as possible through various technological mediums. Therefore, the use of gamification should be utilized as much as possible because according to Park and Kim (2021) it can have a positive effect on student motivation and understanding of learning content. It is very important to ensure that students continue to be developed and their motivation to learn is maintained at a high level as the teaching and learning process less conducted face to face and physically.

\section{Implications of the Study}

The researcher presents three implications of the study conducted, namely the implications on the practice of teachers, students and school administrators. Teachers in the study location schools are less skilled in using ICT facilities to be applied in teaching delivery. There are also teachers who consider the delivery of new pedagogy as difficult. In fact, they think their old teaching experience is mature enough to reject the acceptance of new teaching methods. With this new and potentially evolving method, students will definitely have fun and not want to miss out on the opportunity to follow the learning of every school day. Pupils will be more interested and attracted to digital games because it has become their norm to play naturally.

In addition, their skills such as English communication skills will also increase apart from their reasoning skills using technological tools will be more prominent and developed. Therefore, administrators should always encourage teachers to improve their teaching strategies to new teaching that is more innovative and high-impact with the help of modern technology. The desire to learn new norms in this stream of education should be the starting point for teachers in order to improve the quality of their teaching to a higher level.

\section{Limitations and Suggestions for Further Studies}

Administrators, especially in educational institutions, should seek initiatives to improve teaching and learning infrastructure and facilities for educational use. For example, researchers face the issue of lack of number of computers to be used in student learning. From the linguistic aspect, English language proficiency should be given widespread priority in schools. This is because most modern software today uses English as the main medium of instruction. 
In addition, the administrators should always encourage teachers to attend courses organized, especially courses related to ICT to improve teacher competencies. Furthermore, this study can be applied across the curriculum, for instance this Gamification technique can be implemented for other subjects. Researchers have suggested that further research related to this Gamification technique can be improved by using more difficult topics, increasing the number of respondents, implementing interventions in different locations, taking into account gender factors as variables and using different research instruments.

\section{Conclusion}

Overall, the use of Gamification technique is one of the teaching delivery strategies that have high potential to be further expanded its use in current education. In addition, Gamification techniques have been proven to improve student achievement in learning for Science subjects, especially the topic of Energy. The mean achievement of the treatment group scores showed a higher improvement compared to the teaching delivery using conventional methods. As educators, teachers should have the courage to try this new teaching strategy to be integrated in all subjects across the curriculum as one of the effective strategies in improving the academic performance of students in school. Appropriate teaching strategies and in accordance with student norms have the potential to increase knowledge and attract students' interest in the lesson.

\section{Appreciation}

This article is a study related to STEM Program and Minda, Project Code: GG-2021-001.

\section{References}

Ah-Nam, L., \& Osman. (2017). Developing 21st Century Skills through a ConstructivistConstructionist Learning Environment. K-12 STEM Education, 3(2), 205-216.

Alamri, M. M., \& Almaiah, M. A. (2020). The use of mobile gamification technology for sustainability learning in Saudi higher education. International Journal of Advanced Trends in Computer Science and Engineering, 9(5), 8236-8244. https://doi.org/10.30534/ijatcse/2020/191952020.

Ali, A., \& Zulkifli, Z. (2016). Jurnal Pemikir Pendidikan (2016), 7, 57-72. Jurnal Pemikir Pendidikan. https://doi.org/http://dx.doi.org/10.1093/neuonc/nox036.

Arip, M., \& Sa'ad, F. (2014). Faktor, kesan dan strategi menangani permasalahan kurang tumpuan pelajar sekolah menengah di dalam kelas: suatu kajian kualitatif. International Counseling Conference and Work, 13-15 Sep 2014, Medan.

Barata, G., Gama, S., Jorge, J., \& Gonçalves, D. (2013). Improving participation and learning with gamification. ACM International Conference Proceeding Series. https://doi.org/10.1145/2583008.2583010.

Burke, B. (2013). Gamify: how gamification motivates people to do extraordinary things. Journal of Chemical Information and Modeling. https://doi.org/10.1017/CBO9781107415324.004.

Çankaya, S., \& Karamete, A. (2009). The effects of educational computer games on students' attitudes towards mathematics course and educational computer games. Procedia Social and Behavioral Sciences. https://doi.org/10.1016/j.sbspro.2009.01.027.

Deterding, S., Dixon, D., Khaled, R., \& Nacke, L. E. (2011). From Game Design Elements to Gamefulness: Defining "Gamification". MindTrek'11, 28-30 September, Tampere, Finland. 
Freeman, S., Eddy, S. L., McDonough, M., Smith, M. K., Okoroafor, N., Jordt, H., \& Wenderoth, M. P. (2014). Active learning increases student performance in science, engineering, and mathematics. Proceedings of the National Academy of Sciences of the United States of America. https://doi.org/10.1073/pnas.1319030111.

Hamzah, N., Mistima Maat, S., \& Iksan, H. Z. (2019). The effect of fun and interactive games as a strategy in teaching coordinates to enhance students' performance in Mathematics. Religación. Revista de Ciencias Sociales y Humanidades, 4(22), 274-278. https://doi.org/10.46652/rgn.v4i22.579

Hussain, S. Y. S., Tan, W. H., \& Idris, M. Z. (2014). Digital game-based learning for remedial mathematics students: A new teaching and learning approach In Malaysia. International Journal of Multimedia Ubiquitous Engineering, 9(11), 325-338. doi: http://dx.doi.org/10.3850/978-981-09-0463-0_011.

Jasni, S. R., Zailani, S., \& Zainal, H. (2018). Pendekatan Gamifikasi dalam Pembelajaran Bahasa Arab. Journal of Fatwa Management and Research. https://doi.org/10.33102/jfatwa.vol13no1.165.

Kalogiannakis, M., Papadakis, S., \& Zourmpakis, A. I. (2021). Gamification in science education. A systematic review of the literature. Education Sciences, 11(22), 1-36. https://doi.org/10.3390/educsci11010022.

Khaleel, F. L., Ashaari, N. S., Wook, T. S. M. T., \& Ismail, A. (2016). The architecture of dynamic gamification elements based learning content. Journal of Convergence Information Technology(JCIT), 11(3), 164-177. https://bit.ly/3CMN7QW.

Khaleel, L. F., Ashaari, N. S., \& Wook, T. S. M. T. (2020). The impact of gamification on students learning engagement. International Journal of Electrical and Computer Engineering (IJECE), 10(5), 4965-4972. doi: 10.11591/ijece.v10i5.pp4965-4972.

Kuo, M. S., \& Chuang, T. Y. (2016). How gamification motivates visits and engagement for online academic dissemination - An empirical study. Computers in Human Behavior. https://doi.org/10.1016/j.chb.2015.08.025.

Park, S., \& Kim, S. (2021). Is sustainable online learning possible with gamification? - the effect of gamified online learning on student learning. Sustainability 2021, 13, 4267. https://doi.org/10.3390/su13084267.

Pramana, D. (2016). Perancangan aplikasi knowledge sharing dengan konsep gamification. Jurnal Sistem dan Informatika, 10 (1).

Putz, L. M., Hofbauer, F., \& Treiblmaier, H. (2020). Can gamification help to improve education? Findings from a longitudinal study. Computers in Human Behavior, 110, 106392. https://bit.ly/3tmXnvj.

Rosly, R. M., \& Khalid, F. (2017). Gamifikasi: Konsep \& Implikasi dalam Pendidikan, Pembelajaran Abad ke 21, Trend Integrasi Teknologi. (pp. (pp 144-154)). Bangi: Fakulti Pendidikan UKM. https://www.academia.edu/31631557/Gamifikasi_Konsep_dan_Implikasi_dalam_Pen didikan.

Siong, W. W., \& Osman, K. (2018). Pembelajaran berasaskan permainan dalam pendidikan STEM dan penguasaan kemahiran abad ke-21. Politeknik \& Kolej Komuniti Journal of Social Sciences and Humanities, 3, 121-135.

Smith, R., \& Kilty, L. A. (2014). Crowdsourcing and gamification of enterprise meeting software quality. Proceedings - 2014 IEEE/ACM 7th International Conference on Utility and Cloud Computing, UCC 2014. https://doi.org/10.1109/UCC.2014.95. 
Soh, T. M. T., Osman, K., \& Arshad, N. M. (2012). M-21CSI: A validated 21st century skills instrument for secondary science students. Asian Social Science, 8(16), 38-44.

Sung, H. Y., \& Hwang, G. J. (2013). A collaborative game-based learning approach to improving students' learning performance in science courses. Computers and Education, 63, 4351. https://doi.org/10.1016/j.compedu.2012.11.019.

Zimmerman, D. C. (2010). Project Based Learning for Life Skill Building in 12th Grade Social Studies Classrooms: A Case Study. Postgraduate Thesis, School of Education and Counseling Psychology Dominican University of California San Rafael, CA. https://files.eric.ed.gov/fulltext/ED510590.pdf. 